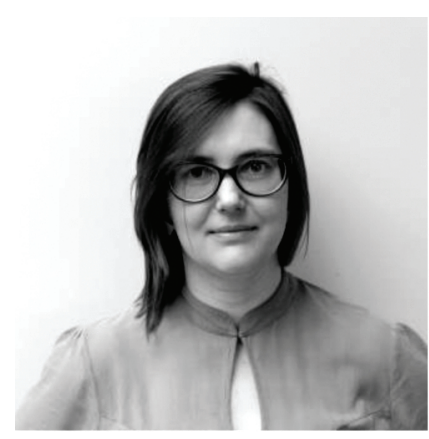

Ieva Tihovska - Latvijos universiteto Literatūros, folkloro ir meno instituto (Ryga) etnomuzikologè

Moksliniai interesai: tautybè, romai, socialiniai judejjimai, tradicinè muzika

El.paštas: ieva.tihovska@gmail.com

Ieva Tihovska - ethnomusicologist at the Institute of Literature, Folklore and Art of the University of Latvia, Riga

Research interests: ethnicity, Roma, social movements, traditional music

E-mail: ieva.tihovska@gmail.com

\title{
Ieva Tihovska
}

University of Latvia

\author{
BROADENING THE SELF AND INCLUDING \\ THE OTHER: 'OTHER ETHNICITIES' \\ IN THE MEDIA AND THE ARCHIVES \\ OF LATVIAN FOLKLORE IN THE LATE $1920 \mathrm{~S}$
}

\begin{abstract}
The foundation of the Republic of Latvia in 1918 changed significantly ethnic relationships in the country. Ethnic Latvians became not only the numerical but also the political and cultural majority, and thereby the concept and status of ethnic minorities were created. This article examines the visibility of ethnic minorities in the newly established state, focusing on the case of the Archives of Latvian Folklore, founded in 1924, as one of the core institutions that strengthened national cultural values. The 'folklore of other ethnicities' category was introduced and discussed at the archive during the first years of its existence. Volunteer folklore collectors played an active role in the discussions, revealing the bottom-up aspects of the implementation of the archive's policy. However, rather than pointing to the ethnic affiliation of the involved people, the archival records reflect more often the blurred linguistic boundaries in Latvian society.
\end{abstract}

KEY WORDS: ethnic minorities, multilingualism, archives, folklore, bottom-up policy.

DOI: http://dx.doi.org/10.15181/rh.v28i0.2227

The power of archives

Since the end of the 20th century, when archival science turned to a selfreflective mode of thought, the inherent political power of archives has been increasingly discerned and discussed (Brown, Davis-Brown 1998; Cook 2001; Schwartz; Cook 2002; Jimerson 2006). Along with museums and libraries, archives are seen as powerful structures, established to sustain the ideology of empires 
and colonial and nation-states to select their symbolic property, to store it and display it, and to build and strengthen society's collective identity. The Canadian archival scientists Joan M. Schwartz and Terry Cook point to the power of archives in shaping academic knowledge and the self-reflection of people: 'Archives as records - wield power over the shape and direction of historical scholarship, collective memory, and national identity, over how we know ourselves as individuals, groups, and societies' (Schwartz, Cook 2002, 2). Archival records are no longer seen as passive, quiet and neutral resources used for believably objective research. On the contrary, they are considered as active users of academic research for delivering their implicit message, be it the superiority of a political order or a social group, or the sacredness of the past, or particular historical events.

Folkloristics is a discipline that is tightly intertwined with the establishment and use of archives. The collection and archiving of folklore have been ways to be acknowledged, materialised and visible in society. In recent decades, folklorists have been reflecting on inclusive and exclusive practices in the work of folklore archives. As Barbro Klein puts it regarding archival practice in her country, 'Swedish folklorists, archivists, and museum employees are beginning to become aware of the exclusions upon which their institutions are built' (Klein $2000,36)$. Folklore research is a result of the richness, or on the contrary, the lack of archival data, and it makes particular social groups visible or invisible for the many people interested in this field.

The idea behind this study is to investigate and discuss the visibility of Latvian ethnic minorities in the Archives of Latvian Folklore. The publication and research of the folklore of Latvia's ethnic minorities has recently become more active. A notable contribution is the series of articles written by the Latvian archivist and folklorist Māra Vīksna (Vīksna 1994, 2003, 2004, 2005, 2017; see also Gehta 2017). Also very important has been the launch of the Digital Archives of Latvian Folklore (www.folklore.lv) in 2014, in which the largest collections of ethnic minority (Russian, Belarusian, Roma, German, Jewish) folklore were published first, pointing to the study of ethnic minorities as one of the priorities of contemporary Latvian folkloristics. Most of these key collections were produced and delivered to the archives in the 1930s and 1940s, when archival principles had already been worked out and established. My research, however, focuses on the very first years of the archive's history, the second half of the 1920s, when the routines and the archival principles were just beginning to emerge. This was when the 'folklore of other ethnicities' (cittautu folklora) category appeared at the archives, and found its way into discussions, documents and reports. What folklore and ideas were covered by the designation 'folklore of other ethnicities'? Were there many actual encounters with members of other ethnic groups? Can 
clear boundaries even be drawn between the folklore of Latvians and other ethnic groups? What is the imagined boundary between the folklore of 'others' and 'one's own people' like, and how is it manifested in folklore texts? These are the questions that motivated the writing of this article.

Another issue concerning the work of the Archives of Latvian Folklore that begs to be discussed is the top-down and bottom-up approaches to the implementation of policy, in this case, meaning the state's cultural policy, which supposedly dictated, or at least influenced, the work of the archives and the choices made when dealing with 'other ethnicities'. On one hand, the archival principles had been defined by legislation, foundational papers, statutes, and other top-down political documents even before the actual archival records came into being, and these formed the general ideological base for the subsequent archival work. On the other hand, the official documents were not always detailed enough to solve all the issues that arose in the daily archival routine. Through this study, I would like to highlight the power of bottom-up processes that sometimes influence decision making more than top-down regulations do.

The last few decades have witnessed an enormous amount of research on policy implementation, and the pros and cons of top-down and bottom-up approaches have been discussed broadly (for an analytical overview, see deLeon, deLeon 2002). Starting in the late 1970s and early 1980s, authors pointed to the weaknesses of the top-down perspective, and 'bottom-upper' arguments became more influential, as Paul A. Sabatier writes:

Rather than start with a policy decision, these 'bottom-uppers' started with an analysis of the multitude of actors who interact at the operational (local) level on a particular problem or issue [...] The fundamental flaw in top-down models [...] is that they start from the perspective of (central) decision-makers and thus tend to neglect other actors. Their methodology leads top-downers to assume that the framers of the policy decision (e.g. statute) are the key actors and that others are basically impediments. This, in turn, leads them to neglect strategic initiatives coming from the private sector, from street level bureaucrats or local implementing officials, and from other policy subsystems (Sabatier 1986, 22, 30)

According to Richard Harvey Brown and Beth Davis-Brown (1998), bottomup technicalities, discussions and solutions in archival work also contain a political dimension, if not explicitly than latently or potentially. Daily decisions are influenced by practical issues, such as the archival budget, physical and computer storage space, or limited staff resources, and these microprocesses become ideo- 
logical and political because they influence directly the building and structuring of archival collections (Brown, Brown 1998, 22).

Discussing diversity governance with regard to the religious pluralisation in contemporary Germany and Switzerland, Duemmler and Nagel point to the power of initiatives coming from the very grassroots of civic society (Duemmler, Nagel 2013,268), and they uphold the combination of a macro-level and mesolevel approach for the successful analysis of policy implementation. In analysing the policy and the work of the Archives of Latvian Folklore, the bottom-up approach seems inevitable, because the participation of society in the collection of folklore was immense. Even if the foundation of the archives was influenced by the ethnic-nationalist idealism of higher governmental institutions, the daily work of the archives soon revealed the necessity to deal with questions about the multiethnic character of Latvian society, both among the archivists and in their communication with the many volunteer workers who wrote down and submitted folklore material.

\section{The discourse on ethnic minorities in Latvia}

In order to contextualise the appearance, reception and conceptualisation of the 'folklore of other ethnicities' at the Archives of Latvian Folklore, in this section I look more broadly at the perception of ethnic 'others' in Latvian society in general. After the declaration of the Republic of Latvia in 1918, a restructuring of society took place, and a category of ethnic minorities emerged next to the new politically dominant, ethnic Latvians. ${ }^{1}$ This process significantly changed the power relationships for previously dominant ethnic groups, such as Baltic Germans, whose political, economic and cultural power, although diminished, still remained relevant, and so the issue of ethnic minorities remained topical in society.

Jaunākās Zinaas (The Latest News), the largest Latvian newspaper of the day, was perused to comprehend the visibility of ethnic minorities in the daily discourse by the general Latvian public. The fact that ethnic minorities actively published media of their own, and maintained independent and lively social and cultural scenes, is not reflected in this article, because of its focus on how ethnic minorities were perceived by ethnic Latvians. While exploring the newspaper, the central questions were: what was the image of ethnic minorities, and what were the main contemporary events, curiosities and fears that the newspaper reveals? The author looked for articles, news and advertisements that mention the ethnic aspect, which does not necessarily mean that members of ethnic mi-

1 According to the 1920 census, ethnic Latvians constituted $72 \%$ of the country's population (Skujenieks 1925, 25). 
norities could not take part in social and cultural life without their ethnicity being emphasised. Because this article analyses the visibility of ethnic minorities, mentioning the ethnic aspect was a determiner.

At an international and national political level, the 1920s were a significant time, when ethnic minorities began to consolidate, unite, and seek representation in organisations: the European Nationality Congress ${ }^{2}$ (1925-1938) and the League of Nations (1920-1946) at an international level, and attempts to create a united minority bloc in the Latvian parliament at the national level (1926). The concept of ethnic minorities was established, their common aims were formulated, and their rights were claimed in the nation-states formed after the First World War. As the Latvian lawyer, university lecturer, politician and analyst Kārlis Dišlers noted: 'One of the most important contemporary political issues is the minority issue, which forms slowly in the process of development of democracy' (Dišlers 1929, 1). In contradiction, at the end of the same article, he wrote:

It is also clear that this issue is slowly losing its acuteness. And that is also understandable, because European political life is normalizing, and the democratic states continue to become stronger; minority issues in several countries are solved fairly satisfactorily, because a democratic state does not want to suppress anybody, and recognises not only the rights of individuals but also of minorities (Dišlers 1929, 1). ${ }^{3}$

This contradiction between the unsolved acuteness of the 'minority issue' on one hand and the already settled status of the issue on the other hand can be encountered also in other issues of the newspaper. The Latvian (as well as Estonian) role in the establishment of the European Nationality Congress, the main interwar organisation of European ethnic minorities, was significant thanks to its ideological and organisational leaders, the Latvian-German politician and journalist Paul Schiemann (1876-1944) and the Estonian-German lawyer Ewald Ammende, among others (Hiden, Smith 2006; Smith, Hiden 2012; Hirschhausen 2010; Housden 2000). In their speeches, the Latvian and Estonian repre-

2 Also, the European Congress of Nationalities.

3 The German historian Ulrike von Hirschhausen points to the difficulties that the European Nationality Congress encountered when trying to formulate a united, common principle for all the different statuses and needs of ethnic minorities in different European countries. Still, the unifying principle of solving the minority issue remained the aim of the congress. 'Established by politicians and intellectuals of various ethnic and religious origins, the Congress strove to internationalize minority rights throughout Europe. Its subsequent evolution reflected the enormous difficulty in translating the specific interests of discrete minorities into an abstract, supranational principle' (Hirschhausen 2010, 104). 
sentatives declared that their respective countries could be acknowledged as good laboratories for solving 'the minority issue' thanks to successful national legislation (JZ 1926, 4). Labelling Estonia a paradise for minorities, Jaunākās Zinas also mentioned Latvia: 'Perhaps on not so great a level, but nevertheless in an approvingly distinguished manner, the issue of minorities has also been solved in Latvia, where the autonomy of education has been established and is extensive enough to satisfy all the demands of minorities' (JZ 1928, 1). So even if at a national level the discussions were sometimes rather tempestuous and ardent, at the international level Latvia was often mentioned as a good example for other countries where the status of minorities was seen to be more problematic (for example, that of Germans in Italy or Hungarians in Romania).

After Schiemann gave a speech on the status of Latvian ethnic minorities to an international congress of parliamentarians in Berlin in 1928, Jānis Rubulis, a member of the Latvian parliament, made the following comment: 'We Latvians hope that the good relationships between ethnic minorities and Latvians portrayed by Schiemann will continue [...] In any case, the situation in Latvia is very satisfactory at the moment. Our minorities have to acknowledge this and be wise enough to not ask for anything more' (Arenštams 1928, 7). This is a key phrase, illustrating the general attitude towards ethnic minorities in Jaunākās Zinas: they can be tolerated well if they are invisible enough and do not propose any new changes for their benefit. Still, the very structure and daily discussions in the Latvian parliament did not quite fulfil this vision. In the second half of the 1920s, 16 to 19 members of parliament (out of a total of 100) represented ethnic minorities. German, Russian, Jewish and Polish factions existed, and the topic of ethnic minorities was always present on the parliament's daily agenda, if not in the form of active discussions regarding the rights of ethnic minorities, then by the very presence of these parliamentarians, because they were regarded as a separate bloc alongside the right wing, the left wing, the centrists and the agrarians, and their voices appeared regularly in the newspaper.

An overall opinion that can be encountered quite often in Jaunākās Zinas is that ethnic minorities demanded too much and were too influential. It is clear that Latvians felt insecure towards the former elite, namely Baltic Germans, as well as towards Jews. These two ethnic groups had the biggest political, economic and intellectual influence, and also debated and defended their rights most visibly. Surprisingly enough, Russians were discussed quite rarely, even though they were numerically the largest ethnic minority at that time. ${ }^{4}$ In general, compared to the positive image of Latvia in the context of other European countries, inter-

4 The 1925 census shows that 12\% of Latvia's population was Russian (Skujenieks 1925, 52). 
nally the situation was much more contradictory, and tensions between ethnic minorities and Latvians were more pronounced.

An event that considerably escalated these tensions was the referendum on the Citizenship Law held in Latvia in 1927. The reason for the referendum was to introduce amendments to the law that broadened the possibilities to obtain citizenship for people who lived in the territory of Latvia before the country declared independence in 1918. The main consideration was to ease the return of First World War refugees, but because the amendments were particularly supported by local Jewish parliamentarians and the media, the initiative was quickly nicknamed 'the Jewish Law', and provoked increasing and heated protests against Jews and other non-Latvians. With slogans such as 'we want to be masters in our own native land', 'vote out the Jews, save Latvia', 'the Citizenship Law is an issue of the survival of the Latvian nation', and 'our duty is to keep Latvia for Latvians', which ranged from anti-semitic to generally xenophobic, people actively expressed their fears. Latvians saw the amendments as a risk that Latvia would be flooded by thousands of non-loyal strangers who had not contributed to gaining independence for Latvia, that the dominance of non-Latvians in the local economy and politics would grow and lead to the deep economic slavery of ethnic Latvians, that Latvia would attract people who were not producers or physical workers but profiteers and seekers of an easy life instead. As the prominent Latvian writer Jānis Akuraters summed it up, the Latvian language and culture would be suppressed, the dream of independence would come to an end, and economic life would also be endangered (Akuraters 1927, 1).

With few analytical articles available, such mostly emotional generalisations destabilised public ethnic relationships in 1927. Schiemann wrote that 'It would be very unwise to put this issue to a referendum, because this would, for the first time in the country's existence, bring the national struggle to the masses' (Šìmanis 1927, 11), and considered it much better if the issues could be solved within parliament.

Another political discussion that considerably shook up Latvian society followed in 1929, and addressed compensation for Baltic German soldiers who had fought in the Latvian War of Independence (1918-1920), and their rights regarding land ownership. Votes were collected that year to initiate a referendum about cancelling these privileges. The process was accompanied by a year-long debate that considered, among other things, the complicated and contradictory role of the Baltische Landeswehr (Baltic German armed forces) in the Latvian War of Independence. Besides the emotions stirred up by the unjustifiably equal rights of Latvian and Baltic German soldiers, protests also turned against the political power and influence of the former Baltic German landowners and their 
descendants, as well as against the 'ill-founded requirements' of other ethnicminority politicians in general.

Besides these two large political campaigns, a number of smaller events and discussions kept ethnic minorities visible in Latvian society. Advertisements regularly appeared for the Russian Drama Theatre, the German operetta, and several other minority theatres, and reviews of their opening ceremonies and premières were published. The theatres were honoured for maintaining and cultivating ethnic minority cultures. This daily and positively neutral presence of ethnic minorities in cultural life intensified in 1928, when a sharp discussion about annual funding for theatres took place. Funding had been cut off for provincial Latvian theatres, but not for ethnic minority theatres, and many saw support for ethnic minority theatres as a threat to Latvian theatrical art. Critical articles with titles such as 'Latvians in the Role of a Minority' and 'Latvian Cultural Institutions are in Danger' were published, and illustrated with a political cartoon of a funeral for provincial Latvian theatres. Another event that caused debate was the introduction in 1927 of draft legislation regarding the Herder Institute, a private institution of higher education for Baltic Germans (1921-1939). There was doubt whether such an institution of higher education was necessary for a minority group. The Herder Institute was seen as a step towards the segregation of Baltic Germans, and potentially also of other ethnic groups in the general population.

Another area that did not remain ethnically neutral was crime news. The ethnicity of perpetrators, particularly when it was Jewish or Roma (Gypsy), was often mentioned when announcing violations of the law, and crime news generally became more tendentious when ethnic matters were being publicly discussed. For example, Jews were most often mentioned in crime news in 1927, when the debate about the 'Jewish Law' (the citizenship law) was taking place, which inflamed the ethnic discourse even more.

Besides the cases mentioned above, the newspaper sometimes published longer, neutral, informative historical or ethnographic articles about local ethnic communities. For instance, the role of Latvian Lithuanians in the gaining of independence by Lithuania was analysed in an article on 16 February 1926, the anniversary of Lithuania's independence. Journalists also wrote a couple of ethnographic reportages on the Roma, a non-institutionalised and 'exotic' local ethnic group.

To sum up, an analysis of the newspaper Jaunākās Zinas shows ethnic minorities as a visible and active part of the political and cultural life of the country. They were recognised in Latvian society, but at the same time an eye was kept on their claims, guaranteeing that they would not dominate over ethnic Latvians in the political, financial or cultural realm. 
The Archives of Latvian Folklore:

ideals, regulations, discussions

The Archives of Latvian Folklore (Latviešu folkloras krātuve) were founded in 1924 in the newly established Republic of Latvia as one of the core institutions storing and representing national cultural values. The archives had a strong focus on collecting and preserving the rural folklore of ethnic Latvians, thereby strengthening the sincerely imagined monoethnic ideal of the nation. The statutes of the archives state that they were founded with the aim 'to promote the collection of monuments to the old Latvian way of life: Latvian folk poetry and traditions', and the declared tasks were 'to collect, compile, preserve, and publish materials of Latvian folklore' (VV 1924, 1). The statutes and the name of the archives indicate that the initial aim was not to cover the folklore of all inhabitants of Latvia, including non-Latvians, who formed around a quarter of society. The archivists were fully occupied by their attempts to get funding and equipment, by working out the principles for compiling the collected material, by registering and cataloging all incoming folklore, and by mobilising people to participate in the collection of material. The basic idea which strongly influenced the archival practice was that Latvians were a small ethnic group that needed to work hard to stand alongside big nations: 'Only by preserving and cultivating the characteristics they developed in previous times can small nations acquire the full and apparent right to stand alongside the big nations of culture' (LFK 1925, 11). The archive's focus on Latvian folklore was also asserted internationally. When the Finnish ethnologist Karl Robert Villehad Wikman asked if the archives had any Swedish material, the answer was: 'Our archives collect only Latvian folklore [but] by chance we also have records in the German and Russian languages' (LVVA 1630-190-468). ${ }^{5}$

Although the archives were focused on collecting the folklore of ethnic Latvians, the multi-ethnic reality of Latvia began to appear in the archival collections and discussions quite soon. Individual folklore texts in other languages arrived in the archives soon after its foundation. For instance, Elfriede Lutz, from the Baltic German community of Hirschenhof, submitted 25 German folklore texts as early as August 1925, before the registering of folklore texts in the archives officially began. ${ }^{6}$ Russian and German texts also came into the archives through old song books compiled in the late 19th and early 20th century, showing that songs in other languages were part of the repertoire of ethnic Latvians.

5 Here and henceforth, the acronym LVVA stands for the Latvian State Historical Archives, and the acronym LFK stands for the Archives of Latvian Folklore.

6 Although the Archives of Latvian Folklore were founded on 2 December 1924, the first records were registered on 3 September 1925, when the actual work of the archives began. 
Valuable evidence of the growing discussion on multilingualism and multiethnicity is revealed in the correspondence between the archives and amateur folklore collectors. These issues were discussed mostly between 1926 and 1929, during the tenure of the director of the archives Anna Bērzkalne. ${ }^{7}$ Altogether, 20 units of correspondence address these issues, and they will be discussed in the next sections of this article. On 16 February 1927, these issues were discussed at a board meeting of the archives. Considering the questions of several volunteers regarding the collection of Russian and Belarusian folklore, the board came to the decision that this was very advisable 'because these materials could help to clarify many questions about Latvian folk poetry and beliefs'. Still, the archives could not afford to support financially the collection of folklore of ethnic minorities (meeting protocol of 16 February 1927). This record points to inter-ethnic comparison as a research method of that time: paying attention to ethnic 'others' was validated because it could give new knowledge about 'ourselves'. This approach has also been observed in the history of the Estonian Folklore Archives by Ergo-Hart Västrik:

When the basis for national culture had been formed, 'others' were also recognized, and studies of ethnic minorities and kindred groups were initiated in accordance with the principles of the historic-geographical method as well as the ideas of the Pan-Finno-Ugric movement. These tendencies reflect evidently the basic necessity to define national identity with the help of or through others as well as the need to associate it with distant 'ethnic relatives' (Västrik 2007, 20-21).

These ideas were also familiar to Latvian folklorists, who were well integrated into the international community of folkloristics. In April 1926, an article about Estonian and Finnish folkloristics was published in the official newspaper Valdības Vēstnesis (Messenger of the Government), and it quoted the Finnish folklorist Kaarle Krohn:

Folklore as the most national field of research is at the same time the most international not only because the researchers of one country cannot live without the materials collected in other countries, and because through this they also recognize the rights of others and others' love for

7 Anna Bērzkalne headed the Archives of Latvian Folklore from their foundation until April 1929, when she was dismissed due to a conflict with the director of the Administration of Monuments, the supervisory institution for the archives at that time. The philologist Kărlis Straubergs, a former minister of education, replaced Bērzkalne on 1 May 1929. 
preserving the intellectual heritage of their own ancestors, but also because this love towards their own ethnicity can be transferred through examples and suggestions from one ethnicity to another' (VV 1926, 2).

Gradually, this idea was also established in the practice of the Archives of Latvian Folklore. The next turn towards the inclusion of non-Latvian folklore in the archives was in 1927, when the archival statistics first included 'folklore of other ethnicities' alongside a list of various folklore genres. Published statistics show that 636 non-Latvian folklore texts had been received by the archives by 1 October 1929 (IMM 1929, 563). The card catalogue for 'folklore of other ethnicities' was also supposedly created during this time, and it shows even more non-Latvian folklore texts than the published statistics. Basically, these were separate non-Latvian texts among the dominating Latvian folklore. Most of these texts were written down at three schools in Latgale (the southeast region of Latvia). The catalogue contains song lyrics, tales, rhymes, riddles, proverbs, beliefs and charms, written down mostly in the Russian and German languages, but also in Polish, Belarusian, Estonian, Lithuanian, Yiddish and Roma. Although a large collection of Latgalian-Russian folklore was received by the archives in 1928 from the educator Ivan Fridrih (LFK [1195], http://garamantas.lv/en/collection/886586/Ivana-Fridriha-Latgales-krievu-folkloras-vakums), it was not included in the card catalogue or the statistics: this collection eventually became 'visible enough' and did not need special archival consideration.

'Should I write down the name of the Jew?' Encounters with ethnic others

One of the intentions of this research was to trace the involvement of people belonging to other ethnic groups in performing, writing down, and submitting folklore to the emerging Archives of Latvian Folklore. The card catalogue and published statistics of the 'folklore of other ethnicities' category can lead to the assumption that the folklore texts thus indexed represented local non-Latvian communities. But the reasoning behind the creation of this category was not so obvious. In fact, only rarely did the catalogue lead to repertoire written down from non-Latvians, and the largest such collection, that of Russians from Latgale collected by Ivan Fridrih, was not even included in it.

The catalogue followed primarily a linguistic approach, indicating folklore in non-Latvian languages written down in a variety of circumstances. Only occasionally are the texts accompanied by remarks that affirm that the collector or performer was indeed a person belonging to another ethnic group. Encounters 
with non-Latvians are also difficult to trace, because when they happened in the Latvian language, they were not included in the catalogue. Another aspect that complicates the search is the fact that the boundaries between ethnic groups are not always clear and distinct, especially in a multi-ethnic and multilingual region such as Latgale and other border regions. All these conditions lead us to the conclusion that the archival category 'folklore of other ethnicities' does not reliably document archival encounters with ethnic minorities.

To elucidate the situation, I will present occasions when archival records have been noted as written down from non-Latvians.

Several bits of information confirm that the collectors or informants encountered local Roma. In 1926, the collector Kārlis Zariņš from Mēdzūla in the central-eastern part of Latvia filled several small notebooks entitled Songs and Romances, and accurately indicated the informants who performed the songs. Six song texts were documented as being from 'a Gypsy woman', but without giving her name, surname or nickname (Bb 37, 242-246a). Five out of six of the song texts are in Latvian, and only one stanza is written down in Romani. These records were not included in the 'folklore of other ethnicities' card catalogue, even though they are most likely testimonies of the local Romani repertoire, knowing that songs in Latvian were not a rarity in the Roma community, and that the motifs of the songs correspond to others documented from Latvian Roma (Tihovska 2017, 105-109). Still, a couple of encounters with Roma are noted in the card catalogue. A stanza written down in Latvian by Bruno Riekstinš has a note that it 'was heard from a Gypsy woman in the Alsunga district' (LFK 72, 13857), and schoolchildren from Irlava submitted numbers from one to ten in the Romani language (LFK 4, 635). There is also a song that has a note indicating 'Gypsy song' (LFK 4, 733), but these materials do not mention the exact people from whom they were heard.

The catalogue includes several direct references to Slavic people. A teacher from Pilskalne in Latgale considered it necessary to note that a pupil who wrote down song texts in the Latvian language was actually a Pole (LFK 200, 465). In another case, a folk belief is accompanied by the note 'What a Russian man from the Ludza district says' (LFK 393, 910); and there are also Russian proverbs with the note 'Written down from the conversations of Latgalian-Russians on a train' (LFK 870, 72-74). An old song book from Kandava in western Latvia contains a note that a song was written down from Cossacks who had no time left to sing more because they had to go and fight in a war (LFK 617, 2785).

As can be seen, these short and episodic remarks let us trace the involvement of ethnic minorities in the formation of the archive collections. A more elaborate case is that of Jānis Sedols from Bārta, a place in southwest Latvia inhabited 
predominantly by Latvians; statistics show that in 1930 the local population was 98\% Latvian. ${ }^{8}$ In May 1927, Sedols wrote to the Archives of Latvian Folklore explaining that there was an old Jew, a small trader, who had heard many folk tales from locals in his travels around southwest Latvia. In the letter, Sedols asked if he should write down the name of the Jew. It may seem an odd question, but it indicates that writing down folklore from non-Latvians may have seemed unusual to him, and he sought guidance. Anna Bērzkalne replied to him that he should write down not only the Jew's name but also the parishes he visited during his travels. She wrote: 'This Jew could be interesting for folkloristics as a distributor of different folk traditions; therefore, you could write down everything from him, including what he has observed about life and customs in different parishes in the past and nowadays' (LVVA 1630-194-81). As a result, Sedols sent the archives not only a fair collection of 24 folk tales written down from this informant, but also many others written down from another local Jew, as well as from a local Pole and a Lithuanian. All the tales were written down in Latvian, and were therefore not included in the card catalogue and statistics of 'folklore of other ethnicities'. This folklore collection shows that language and ethnicity are not necessarily bound to each other, especially in multi-ethnic environments where multilingualism is the norm. This is the case when folklore is not linked to a particular ethnic group but is the common cultural practice of a well-integrated local community.

The correspondence between collectors and archivists reveals that the archival approach towards documenting the folklore of ethnic 'others' was not fully consistent. The initiative to document the non-Latvian heritage usually came from the collectors themselves, who wrote and expressed doubts whether the archive would accept and appreciate such efforts, but also asked for assistance, as in the case of Teodors Rāts, who asked: 'May I also write down folk tales heard from local Germans, and if yes, should I write them in the German or Latvian language?' (LVVA 1630-190-21). Folklorists appeared to be intellectually interested in the cultural contacts and interaction between Latvians and non-Latvians, but both the main goals and the limited financial resources of the archives moderated this interest. Jānis Zvaigzne from southeast Latvia wrote in a letter: 'By the way, some pupils began showing an interest in collecting Russian folklore. Is such an activity advisable, and will the archive accept this folklore?' (LVVA 1630-189167). This time, the archives gave an affirmative answer: 'By all means, it would be good to also collect the folk traditions of Russians living in Latgale, and the archives would gladly receive them; however, for now we cannot promise to pay for this' (LVVA 1630-193-85). To another query about writing down Russian

8 From correspondence with the Museum of Bārta on 25 February 2020. 
and Belarusian folklore in Latgale, the archives replied more strictly and authoritatively: 'It would nevertheless be desirable that you now collect mainly the things prescribed in the General Instructions' (LVVA 1630-194-24), meaning the guidelines for collecting folklore that the archives published in newspapers and sent out to schools. On another occasion, the archives restrained from collecting folklore from Estonian communities living in northeast Latvia, arguing that: 'Estonian researchers have already thoroughly described and studied it, so we do not have to concern ourselves with it any more' (LVVA 1630-195-153, 154).

The opposite approach is expressed in a letter in which the archives asked detailed questions about the coexistence of Latvians with Russian and Polish soldiers on the Žubes farmstead near the Estonian border: 'Maybe you can find out something more about the closer relationship between members of the household and the Russian or Polish soldiers [living with them]. How did the Latvians communicate with them? Did the strangers tell any folk tales, ask riddles, sing songs? Maybe somebody still remembers a song or a legend, or something they learned from them' (LVVA 1630-194-200). Subsequently, the author of the description of the residents at Žubes wrote and published a detailed report: 'The owners were continuously required to put up one or more soldiers [...] None of them can remember a stranger ever telling a story, a custom, or singing a song. As can be surmised, they used gestures in communication with the strangers, and now and then a word in Russian, and over the course of time the strangers learned a few Latvian words, so that is how they got along [...] In such circumstances, Latvians most likely did not learn any songs or customs from the soldiers assigned to live with them' (Bērtiņš 1927, 13-14).

'Jargon words.' The linguistic fusion of Latvian folklore

Regarding the purely social aspects of the 'folklore of other ethnicities' category, this section further explores the blurring of boundaries in language use in Latvian society. Rather than pointing to a particular ethnic affiliation, the archival records more often reveal the multilingual practices of people. The fact that linguistic boundaries are not always fixed and clear can be illustrated by the ethnic melting pot of Latgale. According to the 1925 census, this region in southeast Latvia had only $56 \%$ ethnic Latvians, with the next largest ethnic groups being Russians (31\%), Jews (5\%) and Poles (4\%) (Skujenieks 1925, 54). Taking into account the ethnic diversity of the region, it is not surprising to find that the main folklore collections of 'other ethnicities' came from here. Another 
reason why this region was rich in folklore of 'other ethnicities' is the impressive activity of local schools in writing down folklore. A typical collector of that time was a schoolchild who had been given an assignment to write down folklore from his or her family, relatives and community, or a classroom task in writing down their own repertoire. The archives sent special invitations and instructions to schools, and this long-term campaign resulted in many school collections being registered at the archives in the 1920s to 1940s. Three schools stand out from the others in terms of their collections in languages other than Latvian: Somerseta (LFK [232]), Krāslava (LFK [144]), and Ludza (LFK [548]). These collections together formed the majority of the 'folklore of other ethnicities' submitted to the archives in this period.

The case of the Krāslava secondary school is worth looking at in detail, because it lets us see the impact that archival opinion could have on the formation of folklore collections. The collection of this school consists of four folders registered in the archives from May 1926 until June 1939. The first folder was created in 1926, and consists of nine notebooks written down by six pupils following the instructions given by their Latvian language teacher. It is likely that the folklore collection was not an obligatory task for all the pupils of the school, instead being the voluntary work of individual enthusiasts who each wrote down sizable collections. After these materials were sent to the archives, the director of the school received a letter: 'Dear Mr J. Priede, the Archives of Latvian Folklore heartily thank your pupils and the Latvian language teacher for the children's songs and other folk songs submitted. It is very essential that your school continues to diligently collect folk traditions, because Krāslava is located in a very interesting area, where the cultures of several ethnic groups intersect, and that is why the traditions of this region are especially important to folklorists' (LVVA 1630-192-147). Following this letter, the next materials sent in by the school in 1928 and 1930 were organised differently, showing that the school's strategy of folklore collection had changed. The word 'classwork' noted on one page lets us assume that writing down folklore became a part of the lessons. The collections no longer consisted of filled notebooks. Instead, the materials were recorded on loose sheets of paper, compiled according to the school year of the pupils (grades 1 to 4). The number of children involved also increased, although the amount of folklore written down by each pupil was smaller. These manuscripts show a rich variety and mixture of languages even on a single page: the Latvian language can be seen next to Russian, as well as Polish, Yiddish, Belarusian and German texts. This part of the collection fully shows the multilingualism of the local society, and also confirms that the archivists' instructions were an effective tool in shaping the emerging content of the archives. Eventually, however, the 
Krāslava school returned to its previous approach, and the materials it submitted in the 1930s were again only in the local Latvian dialect. This case leads us to believe that if the archival initiative and instructions had been more active and persistent, the archives would have received even more multi-ethnic materials from the communities where multilingualism was the norm.

So far, this article has focused on cases in which the 'folklore of other ethnicities' was written down either from non-Latvians or in multilingual communities. But the 'folklore of other ethnicities' card catalogue has two more categories of folklore texts: those that document the occasional appearance of non-Latvian languages, and the use of stylised foreign languages in the repertoire of ethnic Latvians. In the 1920s, such cases were included in the 'folklore of other ethnicities' category, because they did not represent the imagined pure Latvianness that was sought in folklore. Such filtering reveals efforts to purify Latvian folklore, as well as the general belief that ethnicity can be equated with language. Some more cases illuminate this process in the formation of Latvian folklore.

The correspondence shows the efforts of both collectors and archives to define the attitude towards mixed languages. A couple of times, the issue appeared concerning Latgalian folklore, with collectors asking how individual Russian words that appear in Latgalian texts should be documented. A collector from Daugavpils called J. Liepinšs wrote: 'I held back several songs because they contain Russian words (they are still with me). I don't know whether to keep the Russian words as they are, or to replace them with corresponding Latvian words?' (LVVA 1630-189-318). The reply of the archives clearly stated that the materials should reflect the language as used by the people, even if they contain words in other languages: 'Best of all is to write down everything exactly as your informants said it, also keeping any words in foreign languages, if they are commonly used, because it is important for the archives to receive folk traditions in the language that the people use' (LVVA 1630-194-146).

Similar issues were discussed concerning folklore that came from people living close to the Latvian-Lithuanian border. A collector from the very southwest corner of Latvia (Rucava) asked about the materials narrated by his mother, who lived in Lithuania in her youth and knew many Lithuanian songs with 'a lot of Latvian language mixed in' (LVVA 1630-189-290). The archives replied: 'You can write down all the songs that the old singer knows, also those that are half in Lithuanian' (LVVA 1630-194-84). However, in another case in which the singer was described as knowing many Lithuanian songs from the border with Latvia (Laižuva), the archives replied in a more restrained manner: 'Regarding Lithuanian songs, they might be of considerable interest to researchers in some cases, but the archives' resources are too small to pay for the collection of these 
songs before everything that concerns our own people has been collected' (LVVA 1630-195-139).

Mixtures of languages or stylised foreign languages are sometimes accompanied by a note stating, for instance, 'neither this nor that' (LFK 338, 280), 'jargon words' (LFK 193, 350-355), or 'droll language' (LFK 548, 1260, 1445-1446). Such language mixtures in the archival collections have already been analysed by Māra Vīksna, who writes: 'At times it is not even possible to identify the language of the recorded material. We encounter this problem in medleys, linguistic expressions used in nursery rhymes, incantations, as well as in the interchange of Latvian and German words' (Vīksna 1994, 24). A couple of notes give more context to the use of such texts. The collection of K. Jansons from Durbe contains a short song text in mixed Latvian and Russian, along with the comment: 'This little song is meant for children. The grandfather enjoys reciting it when teaching Russian to the child' (LFK 785, 175). A collection from Latgale written down by Vladislavs Bojars provides some information on the use of the Russian language by Latgalians. He wrote down the 'song' of a blackbird (strazds) in Russian (LFK 67,512 ), and clarified that the old people sorted birds according to their 'ethnicity', and the blackbird was considered to be Russian. Further, he provided some more song texts in Russian, with the remark that 'the old people sang these songs without any sense or understanding of how to speak Russian' (LFK 67, 740-41). These cases show the efforts of folklorists to 'clean up' Latvian folklore, despite the fact that playing with foreign linguistic elements can be a feature of everyday language. Also, it blurs the category of 'folklore of other ethnicities' even more, and confirms once again that this category indicates linguistic content as much as social context, and only an examination of individual cases can reveal why a particular text was included in the category.

\section{Conclusion}

The history of the Archives of Latvian Folklore is an example of how a newly established state was defined and maintained through ideological and practical solutions, and how a diverse society collaborated in this process. The formation of the archives was an early crowdsourcing project, in which the archivists constantly interacted with people from different social environments and identities. The ethnic and linguistic heterogeneity of society appeared to be a debatable issue, due to the imagined and ideal homogeneity of the nation. By creating the category of 'folklore of other ethnicities', room for an isolated heterogeneity was found. However, after folklore texts performed or collected by members of ethnic minorities, this category also covered the multilingual practices of ethnic 
Latvians and people with mixed ethnic identities. Therefore, the study of the visibility and inclusion of ethnic Others turned into a discussion on the imagined and the actual Self. What a hundred years ago was an issue of excluding and 'othering', today can be seen as the potential to broaden the understanding of the Self. Through research, 'folklore of other ethnicities' can be brought back into the historical social and linguistic practices of the inhabitants of the country, and seen without the ideological filter of separation, thereby contributing to a more holistic view of society.

\section{References}

Akuraters 1927 - Jānis Akuraters. Tautas nobalsošana. Jaunākās Zinasas, 281, 1.

Arenštams 1928 - Arveds Arenštams. Dr. Šīmans 'pasaules parlamentā'. Jaunākāas Zinasas, 192, 7.

Bērtiņš 1927 - J. Bērtiņš. Žubes un žubenieši. Rīga: Latv. zemnieku savienība.

Brown, Davis-Brown 1998 - Richard Harvey Brown, Beth Davis-Brown. The making of memory: the politics of archives, libraries and museums in the construction of national consciousness. History of the Human Sciences, 11(4), 17-32.

Cook 2001 - Terry Cook. Fashionable Nonsense or Professional Rebirth: Postmodernism and the Practice of Archives. Archivaria, 51, 14-35.

Cook, Schwartz 2002 - Terry Cook, Joan M. Schwartz. Archives, Records, and Power: From (Postmodern) Theory to (Archival) Performance. Archival Science, 2, 171-185.

deLeon, deLeon 2002 - Peter deLeon, Linda deLeon. What Ever Happened to Policy Implementation? An Alternative Approach. Journal of Public Administration Research and Theory: J-PART, 12(4), 467-492.

Dišlers 1929 - Kārlis Dišlers. Minoritātu jautājums Tautu savien̄̄bas padomē. Jaunākāas Zingas, $144,1$.

Duemmler, Nagel 2013 - Kerstin Duemmler, Alexander-Kenneth Nagel. Governing Religious Diversity: Top-down and Bottom-up Initiatives in Germany and Switzerland. Integrative Physiological and Behavioral Science, 47, 265-283.

Gehta 2017 - Marina Gehta. Giršas Etkina folkloras kolekcija Latviešu folkloras krātuvē. In Ebreju Rēzekne: rakstu krājums, ed. by Ineta Zelča Sīmansone (pp. 159-176). Riga: Creative Museum.

Hiden, Smith 2006 - John Hiden, David J. Smith. Looking beyond the Nation State: A Baltic Vision for National Minorities between the Wars. Journal of Contemporary History, 41(3), 387-399.

Hirschhausen 2010 - Ulrike von Hirschhausen. From Minority Protection to Border Revisionism: The European Nationality Congress, 1925-38. In Europeanization in the Twentieth Century: Historical Approaches, ed. by Martin Conway, Kiran Klaus Patel (pp. 87-109). Hampshire, New York: Palgrave Macmillan.

Housden 2000 - Martyn Housden. Ewald Ammende and the Organization of National Minorities in Inter-war Europe. German History, 18(4), 439-460.

IMM 1929 - [Anonymous.] Latviešu folkloras krātuve. Izglītỉbas Ministrijas Mēnešraksts, 12, 561566.

Jimerson 2006 - Randall Jimerson. Embracing the Power of Archives. The American Archivist, 69(1), 19-32.

JZ 1926 - [Anonymous.] Baltijas valstu minoritātu konference Rīgā. Jaunākās Zingas, 13, 4.

JZ 1928 - [Anonynous.] Minoritātu paradīze. Jaunākās Zinaas, 6, 1.

Klein 2000 - Barbro Klein. "Folklore, Heritage Politics and Ethnic Diversity": Thinking About the Past and the Future. In Folklore, Heritage Politics and Ethnic Diversity: A Festschrift for Barbro Klein (pp. 23-36). Botkyrka: Multicultural Centre. 
LFK 1925 - [Anonymous.] Latviešu folkloras krātuve. Rīga: Latviešu folkloras krātuve.

Sabatier 1986 - Paul A. Sabatier. TopDown and BottomUp Approaches to Implementation Research: a Critical Analysis and Suggested Synthesis. Journal of Public Policy, 6(1), 21-48.

Skujenieks 1925 - Marğers Skujenieks. Otrā tautas skaitǐ̌̌ana Latvijā 1925. gadā 10. februārī. Rīga: Valsts statistiskā pārvalde.

Smith, Hiden 2012 - David J. Smith, John Hiden. Ethnic Diversity and the Nation State: National Cultural Autonomy Revisited. London, New York: Routledge.

Šìmanis 1927 - Pauls Šìmanis. Kas būs ar pavalstniecības likumu Saeimas rītdienas sēdē! Jaunākās Zinas, 99, 11.

Tihovska 2017 - Ieva Tihovska. İsta čigānu mūzika: autentiskums un etniskums Latvijas čigānu (romu) mūzikā. Rīga: Literatūras, folkloras un mākslas institūts.

Västrik 2007 - Ergo-Hart Västrik. Archiving Tradition in a Changing Political Order: From Nationalism to Pan-Finno-Ugrianism in the Estonian Folklore Archives. In Culture Archives and the State: Between Nationalism, Socialism, and the Global Market. Mershon Center, Ohio State University. Available: https://kb.osu.edu/bitstream/handle/1811/46903/ FolkloreCntr_2007conference_Vastrik7.pdf?sequence $=1$

VV 1924 - [Anonymous.] Noteikumi par Latviešu folkloras krātuvi. Valdības Vēstnesis, 274, 1.

VV 1926 - [Anonymous.] Igauñu un somu folkloristiskais darbs. Valdības Vēstnesis, 79, 2.

Vīksna 1994 - Māra Vìksna. Folklore Materials of Ethnic Minorities in the Latvian Folklore Archives. Ejiet un Māciet, 2, 24-29.

Vīksna 2003 - Māra Vīksna. Lībiešu bērnu un jauniešu savāktais folkloras materiāls. In Lībiešu gadagrāmata, ed. by Baiba Šuvcāne (1. 84-98). Mazirbe: Valsts īpaši aizsargājamā kultūrvēsturiskā teritorija "Lībiešu krasts".

Vīksna 2004 - Māra Vīksna. Baltkrievu folklora Latvijā. In Латвiя - Беларусь: дыıялог двух культур. Матэрыялль I Міжнароднай навукова-практычнай канферэнцьі (с. 58-63). Рыга: Саюз беларусаў Латвіi.

Vīksna 2017 - Māra Vīksna. Latgales baltkrievu tautas gara mantas: Sergejs Saharovs un baltkrievu folklore Latvijā: cittautu folkloras pieraksti Latviešu folkloras krātuvē. In Saprast Baltkrieviju: krājums, ed. by Voldemārs Hermanis (1. 48-59). Rīga: Zelta grauds.

Vīksna 2005 - Māra Vīksna. Ievadam. In Čigānu rakstnieka Jura Leimaṇa Čigāni: Latvijas mežos, mājās un tirgos (1. 5-23). Rīga: Zinātne.

\section{Иева Тиховска}

\section{РАСШИРЕНИЕ СЕБЯ И ВКЛЮЧЕНИЕ ДРУГОГО: «ДРУГИЕ НАЦИОНАЛЬНОСТИ»В СМИ И ХРАНИЛИЩЕ ЛАТЫШСКОГО ФОЛЬКЛОРА В КОНЦЕ 1920-Х ГОДОВ}

Резюме

В конце 1920-х годов, когда в архивной науке произошёл поворот на саморефлексный подход, архивы, так же музеи и библиотеки, стали считаться мощными институтами, которые созданы для укрепления идеологии империй, колоний и национальных стран и для отбора, хранения и демонстрации их символической собственности, а также для формирования и укрепления коллективной идентичности обществ. Фольклористика - это отрасль, ко- 
торая тесно связана с созданием и использованием архивов. В последние десятилетия фольклористы оценили подходы включающие и исключающие фольклорные архивы. В фольклорных исследованиях отражается богатство архивных материалов или их отсутствие, и это делает определённые группы общества видимыми или невидимыми для многих людей, заинтересованных в этой отрасли.

Целью этого исследования является изучение видимости национальных меньшинств в латвийских СМИ и Хранилище латышского фольклора во второй половине 1920-х годов - в первые годы существования этого национального архива, когда формировались принципы его работы. Именно тогда в обсуждениях, документах и отчётах архива появилась категория «фольклор других народов». Какой фольклор и какие идеи были в этом обозначении? Часто ли архив встречался с представителями национальных меньшинств? Всегда ли чётко ясна грань между фольклором латышских и других этнических групп? Это вопросы, на которые пытаюсь ответить в этой статье. В статье делается вывод, что архивные единицы, которым дано обозначение «фольклор других народов», чаще всего указывали не на этническую принадлежность вовлечённых лиц, а на расплывшиеся лингвистические границы в латвийском обществе.

С этим исследованием я бы хотела обратить внимание на реализацию политики «снизу вверх» (bottom-up), которая иногда влияли на политику и работу архива больше, чем регуляция «сверху». Анализируя работу Хранилища латышского фольклора, подход «снизу вверх» оправдан, поскольку участие общественности в сборе фольклора было огромное. Даже если на создание архива повлиял идеализм этнического национализма, на повседневную работу архива вскоре повлиял мультиэтнический характер латвийского общества, с которым столкнулись как архивисты, так и добровольные собиратели фольклора.

Основание Латвийской Республики в 1918 году существенно изменило этнические отношения на этой территории. Латыши стали не только численным, но также политическим и культурным большинством, и в результате возникло понятие и статус этнических меньшинств. Количество национальных меньшинств в Латвии было значительным - они составляли примерно четвёртую часть латвийского общества. Для получения более широкого социального контекста в изучение Хранилища латышского фольклора, была так же рассмотрена самая популярная латышская газета того времени «Jaunākās Ziņas», чтобы узнать, что латвийское общество думало о национальных меньшинствах во второй половине 1920-х годов. 
The article is written within the ERDF-funded postdoctoral research project "Digital resources, politics and cultural visibility of ethnic minorities in Latvia" (1.1.1.2/VIAA/1/16/220).
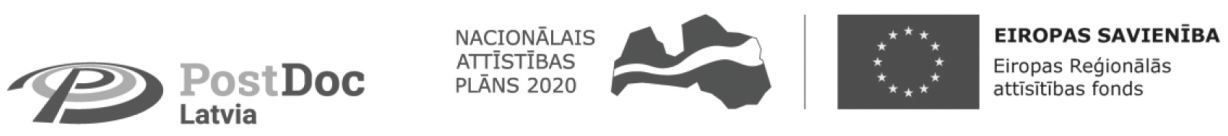

I EGULD I J U M T T 